\title{
28. BIOSTRATIGRAPHIC SYNTHESIS: HIATUSES AND UNCONFORMITIES
}

\author{
Robert G. Douglas, Department of Geology, Case Western Reserve University, Cleveland, Ohio \\ Peter H. Roth, Scripps Institution of Oceanography, La Jolla, California \\ and \\ T. C. Moore, Jr., Department of Oceanography, Oregon State University, Corvallis, Oregon
}

\section{INTRODUCTION}

One or more stratigraphic gaps or hiatuses were detected or inferred at each of the sites drilled during Leg 17. Most prominent of these was an apparent hiatus between middle Eocene and Cretaceous sediments, with all or most of the lower Eocene and Paleocene missing at each of the sites. Several of the hiatuses recognized in the central North Pacific appear to be related to similar stratigraphic discontinuities described by earlier legs in the Pacific Ocean (Fischer et al., 1971; Winterer et al., 1971; Tracey et al., 1971) and perhaps even in the Atlantic Ocean (Pimm and Hayes, 1972). Because the hiatuses have a fundamental bearing on understanding the local and ocean-wide geological history of the Pacific, we describe here the stratigraphic and paleontological data which define or set the boundary condition for the major hiatuses detected during Leg 17. Unfortunately, drilling conditions which result in limited or incomplete core recovery make it difficult to discriminate between a geological hiatus and what might be termed an information gap. We have used the definition of a hiatus suggested by Pimm and Hayes (1972), which is: (1) where a significant gap is indicated by an abrupt discontinuity in the paleontologic ages within a cored interval or (2) where the calculated average accumulation rate between cored intervals is less than $1 / 10$ of the accumulation rate typical for the sediment type believed present in the uncored interval. When the calculated accumulation rate for uncored intervals is between $1 / 3$ to $1 / 10$ less than the typical rate, a hiatus is inferred.

Stratigraphic correlation of the sites drilled during Leg 17, including the major hiatuses, is shown in Figure 1, and the estimated magnitude of the hiatuses is shown in Figure 2.

In addition to the above, several unconformities which do not satisfy the criteria listed above were detected from geophysical evidences. Two of these occur at Site 167. At 232 meters (base of Core 9) in the early Miocene, an angular unconformity is shown in the airgun profile record and is suggested by a change in lithification and GRAPE density. However, there is no apparent paleontological discontinuity between Cores 9 and 10 . Again at 592 meters, between Cores 31 and 32 in the Eocene, geophysical evidence indicates a stratigraphic discontinuity, but no time gap was detected from the paleontological data.

\section{EARLY TERTIARY HIATUS}

The most prominent and widespread startigraphic discordance occurs between the early Tertiary and latest
Cretaceous (Figure 2). However, the magnitude and nature of the discordance vary at each site.

On Horizon Guyot (Site 171) which is the shallowest drill site $(2,290 \mathrm{~m})$ Eocene sediments rest upon late Maastrichtian sediments. The contact is gradational rather than sharp, however. Core 8 and the upper part of Core 9 contain predominantly middle Eocene microfossil assemblages mixed with foraminifera of early Eocene, Paleocene, and Maastrichtian age and nannofossils of Maastrichtian and Paleocene age. In the lower sections of Core 9 the assemblages are late Maastrichtian with a few Eocene and Paleocene microsossils. The Tertiary-Cretaceous boundary is placed at the bottom of Core 9, Section 4 where the foraminiferal and nannofossil assemblages change from predominantly Eocene to predominantly Mastrichtian.

The nature of the boundary suggests that the contact is erosional and the Paleocene and early Eocene sediments were deposited (and preserved) on Horizon Guyotsomewhere upslope from the drill site for they are found reworked into the Oligocene section. The few Tertiary microfossils which occur in the lower part of Core 9 are probably downhole cavings and indicate the degree of drilling disturbance in the core.

The magnitude of the hiatus at Site 171 appears to be from the late Middle Eocene to late Late Maastrichtian.

Definition of the early Tertiary hiatus at the other sites is complicated by poor core recovery and/or poor fossil control. At Site 167 an inferred hiatus involving the early Eocene and late Paleocene occurs between Cores 37 and 38 and a questionable hiatus involving the early Paleocene and latest Maastrichtian occurs between Cores 40 and 41 . Chert was encountered in Core 33, and core recovery in the next nine cores is limited to core-catcher samples. Radiolaria and nannofossils indicate an orderly sequence of increasingly older paleontological zones down to Core 37, but the stratigraphic levels from which the core-catcher samples obtained in these cores were derived within the interval between 629 meters and 648 meters is impossible to determine because of the poor recovery. The core catcher of Core 38, at 657 meters, contains middle Paleocene microfossils. Thus, if we assume that the Eocene sediments of Core 37 are from the drilled interval, then the stratigraphic distance between the middle Eocene (N.P. 15; T. triacantha Zone) and the middle Paleocene (P. 3; N.P. 5) of Core 38 may be as great as 20 meters or less than 1 meter. In either case a hiatus is very probable by the criteria defined above. The stratigraphic relationship between the Paleocene and Maastrichtian, between Cores 40 and 41, is complicated by the incomplete core recovery. As before, only core-catcher samples were obtained in the critical 


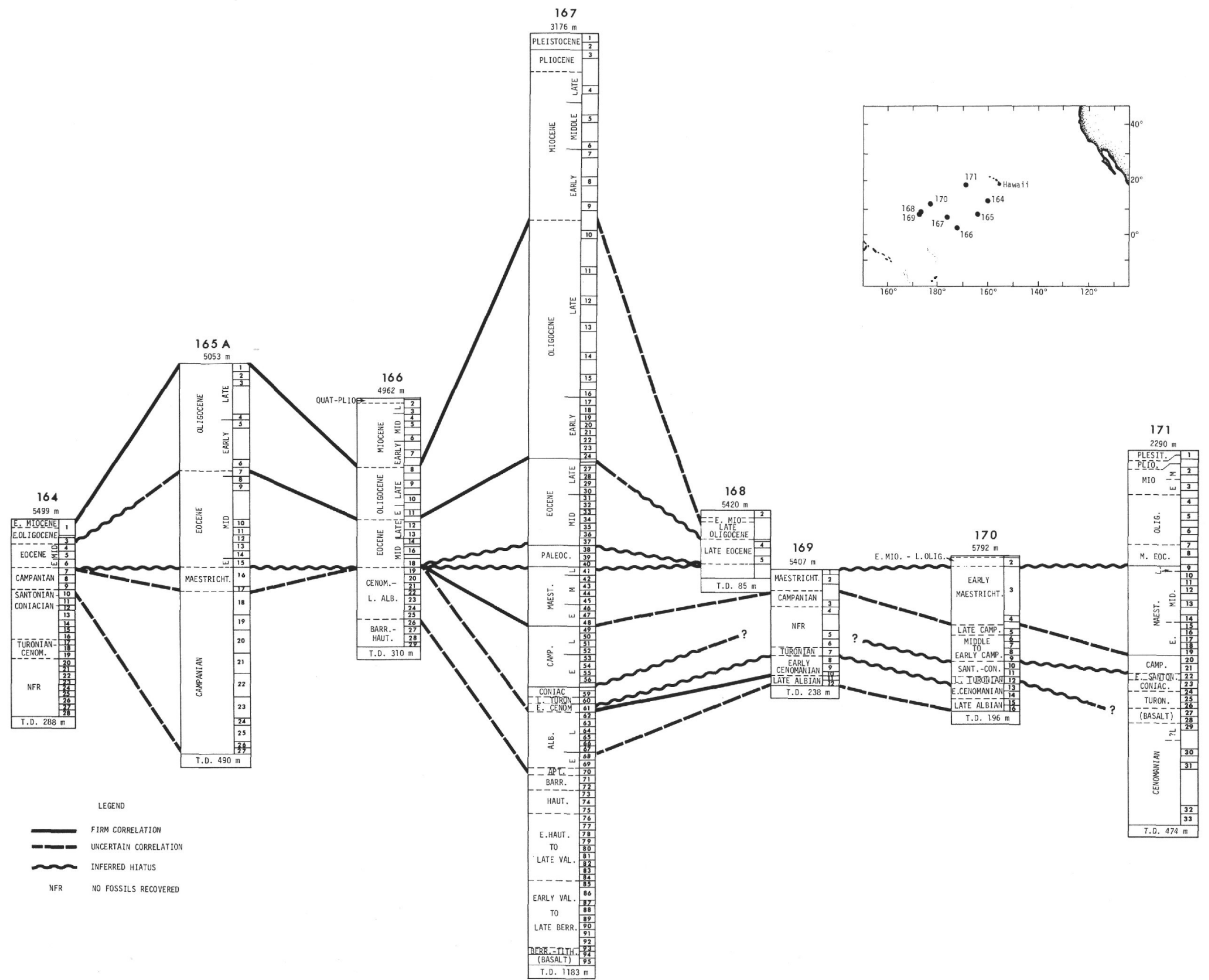




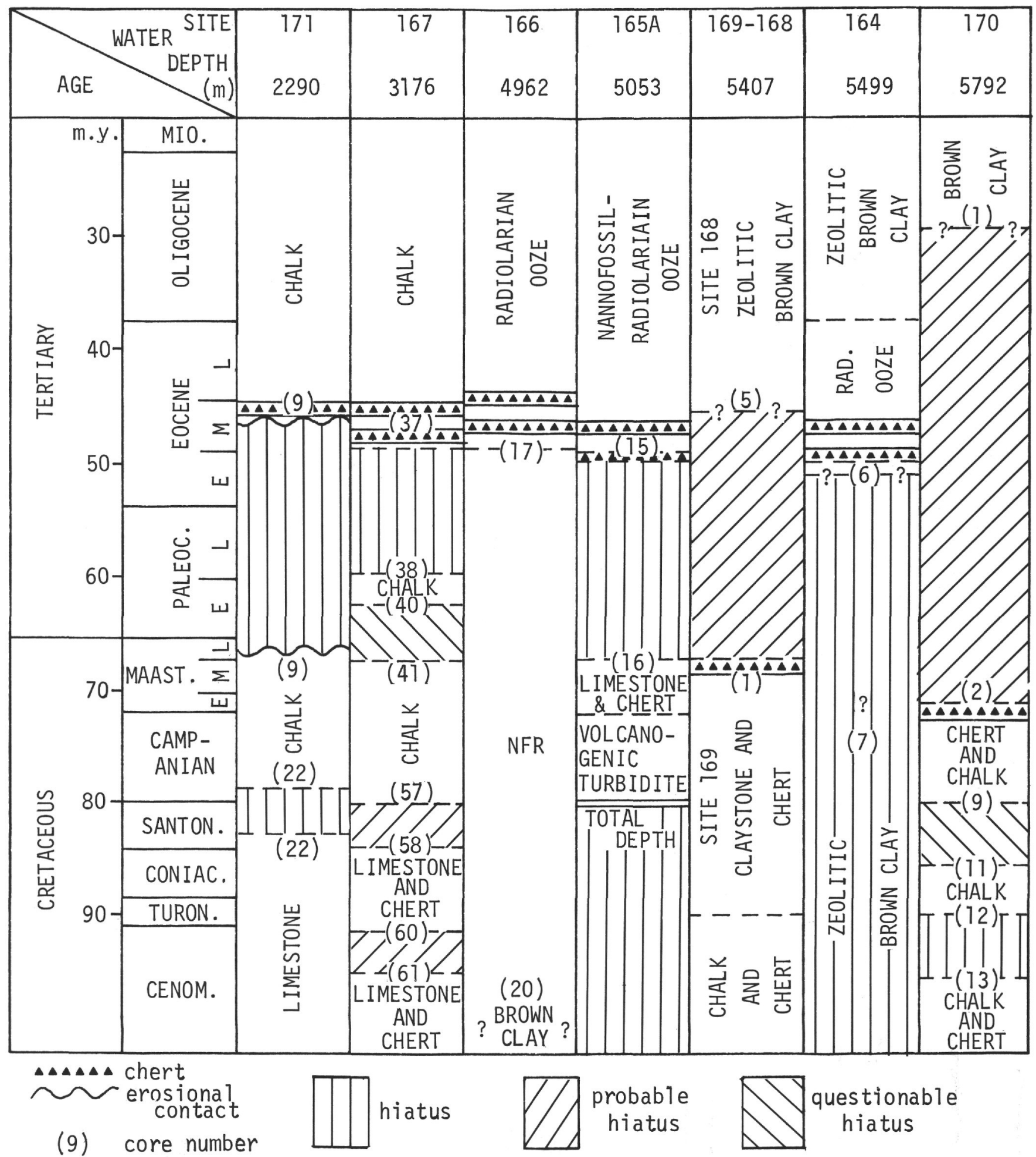

NFR no fossils recovered

Figure 2. Major hiatuses found in sections drilled at Leg 17 sites.

interval. The first Cretaceous fossils encountered downsection are rare foraminifera present in the highly admixed residue of chert fragments and downhole cavings in Core 40 , core catcher. We believe that these microfossils are probably reworked, that Core 40 is middle Paleocene, and that the Tertiary-Cretaceous boundary occurs somewhere within the interval of Core 41. However, we cannot exclude the possibility that a complete section of Danian and latest 
Maastrichtian is contained in the interval between 666 meters (top of Core 40) and 685 meters (bottom of Core 41).

The boundary conditions at Sites 164, 165, and 166 differ from Sites 171 and 167 in that a change in lithology occurs at the contact, and all three sites are in water depths of around 5000 meters or more. At Site $165 \mathrm{~A}$ early Eocene radiolarian ooze (Core 15) overlies late Maastrichtian marl turbidites (Core 16). Chert was encountered in Core 14, and recovery below this level was limited to core-catcher samples. The hiatus at this site is very similar in magnitude to the gap at Sites 167 and 171. The upper boundary of the hiatus can be identified as early Eocene radiolarian ooze and chert at Site 164, but the lower boundary cannot be determined within the Cretaceous. Chert occurs in Core 4, and core recovery in this core and in Cores 5 and 6 was limited to core-catcher samples and partial core sections. No calcareous fossils occur in any of the cores. Radiolaria date Core 6 as probable early Eocene and Core 7 as probably Campanian to Maastrichtian.

The situation at Site 166 is similar to that at Site 164 . Middle Eocene radiolarian ooze overlies brown clay of Cretaceous age. However, between the chert and ooze of Core 17, which contains poorly preserved middle Eocene Radiolaria, and Core 19, which contains a few Late Cretaceous foraminifera, no fossils were found. The foraminifera in Core 20 are probably of middle Cretaceous age (Albian-Cenomanian) but precise age identification is impossible. Thus an interval of 23 meters may represent nearly 50 million years. This figures out at $0.5 \mathrm{~m} / \mathrm{m}$.y. Thus a hiatus is required in the section at Site 166 by our above definition.

Drilling discontinuities impose special problems in interpretation of the cored sections at Sites 168, 169 and 170. Two holes were drilled in the same area at Sites 168 and 169. Site 169 was begun at a level which was projected to be below the Tertiary section obtained at Site 168. Site 168 bottomed at 75 meters in middle Eocene strata, and the first core at Site 169 was taken at 95 meters in Cretaceous chert and claystone. The 20-meter interval spans an apparent time gap of about 20 million years. A hiatus seems probable at this location based on the accumulation rate and acoustic profiles record.

Core 1 at Site 170 was drilled between the sea floor and 15 -meter subdepth. The second core was drilled between 15 meters and 75 meters. In the 49 meters between Core 1 and Core 2, the section passes from early Miocene-late Oligocene to early Maastrichtian. As at Sites 168 and 169, a hiatus seems probable based on the accumulation rate and the profiles record.

In summary, the following features characterize the Tertiary-Cretaceous hiatus at the seven sites:

1) The overlying Tertiary rocks are middle or latest Early Eocene, except at Sites 168 and 169 (late Eocene) and 170 (Miocene-Oligocene). However, biostratigraphic control was poor at the latter site and a coring gap exists between Tertiary and Cretaceous samples.

2) The underlying Cretaceous rocks are mostly late Maastrichtian, except for Sites 164 and 166. The Cretaceous seems to be considerably older at these sites, but fossil control is poor.
3) In the continuously cored holes $(164,165,166$, and 167) core recovery was limited to incomplete cores and/or core-catcher samples in the interval between the Eocene cherts and the underlying Cretaceous. The poor core recovery associated with drilling chert beds prevents precise definition of the magnitude of the inferred hiatus.

4) At Site 171 and perhaps Site 167 the hiatus is associated with an erosional unconformity. It is impossible to determine the nature of the contact at the other drilling sites.

5) There is no obvious relationship between present water depth at the drilling sites and the apparent magnitude of the lower Tertiary-Cretaceous hiatus. The hiatus seems to be smallest at Site 167 and greatest at Site 166, but they are neither the shallowest nor deepest sites. Restoring the sites to their original water depth, using the assumption and curve of Sclater, Anderson, and Bell (1971), fails to produce any improvement in the correlation between water depth and magnitude of the hiatus at each site.

\section{SANTONIAN HIATUS}

There is evidence at Sites 171,167 , and possibly 170 for a stratigraphic gap involving portions or all of the Santonian. The strongest evidence occurs at Site 171 where a lithologic change coincides with a paleontological break within the top of Core 22. A lithologic change seems to coincide with a paleontological break at Site 167 but the fossil control is poor. Benthonic foraminifera are Campanian in Core 57 and probably Coniacian or older in Core 58. Nannofossils suggest Core 57 is Campanian and Core 58 is Santonian or Coniacian. This level corresponds to an unconformity which shows on the acoustical profiles records and a change in sonic velocity.

At Site 170 a hiatus may occur in about the same position as at Sites 167 and 171 . Core recovery is poor and yielded only poorly preserved nannofossils.

\section{CENOMANIAN HIATUS}

Late Cenomanian microfossils seem to be absent in several places in the Pacific (Douglas, 1971). At Site 167 Core 60 contains Turonian nannofossils. The incomplete sections and core-catcher samples from Core 61 contain only early Cenomanian foraminifera and coccoliths. A hiatus seems possible. At Site 170, the paleontological situation is similar.

\section{REFERENCES}

Douglas, R. G., 1971. Cretaceous foraminifera from the northwestern Pacific Ocean: Leg 6, Deep Sea Drilling Project: Initial Reports of the Deep Sea Drilling Project, Volume VI. Washington (U.S. Government Printing Office), p. 1027-1053.

Fischer, A. G., Heezen, B. C., Boyce, R. E., Bukry, D., Douglas, R. G., Garrison, R. E., Kling, S. A., Krasheninnikov, V., Lisitzin, A. P., and A. C. Pimm, 1971. Initial Reports of the Deep Sea Drilling Project, Volume VI. Washington (U. S. Government Printing Office), 1329 p.

Pimm, A. C. and Hayes, D. E., 1972. General Synthesis: Initial Reports of the Deep Sea Drilling Project, Volume XIV. Washington (U. S. Government Printing Office), p. 955-975.

Sclater, J. G., Anderson, R. N., and Bell, M. C., 1971. Elevation of Ridges and Evolution of the central eastern Pacific: J. Geophys. Res., v. 76, p. 7888. 
Tracey, J. I., Sutton, G. H., Nesteroff, W. D., Galehouse, J., Von der Borch, C. C., Moore, T. C., Lipps, J., Haq, V. Z., and Beckmann, J.P., 1971. Initial Reports of the Deep Sea Drilling Project, Washington (U. S. Government Printing Office), 1037 p.
Winterer, E. L., Riedel, W. R., Brönnimann, P., Grealy, E. L., Heath, G. R., Kroenke, L., Martini, E., Moberly, R., Jr., Resig, J., and Worsley, T., 1971. Initial Reports of the Deep Sea Drilling Project, Volume VII. Washington (U.S. Government Printing Office), 1757 p. 